Received $\quad 19.02 .2016$ Reviewed 29.03.2016 Accepted 25.06.2016

A - study design

B - data collection

C - statistical analysis

D - data interpretation

$\mathbf{E}$ - manuscript preparation

F - literature search

\section{Sediment load estimation} in the Mellegue catchment, Algeria

Kaouther SELMI ${ }^{\mathrm{ABCDEF}}$, Kamel KHANCHOUL ${ }^{\mathrm{ACDEF}}$ Laboratory of Soils and Sustainable Development, Badji Mokhtar University-Annaba, Algeria;
e-mail: kaouther_selmi@yahoo.fr, kkhanchoul@yahoo.fr

For citation: Selmi K., Khanchoul K. 2016. Sediment load estimation in the Mellegue catchment, Algeria. Journal of Water and Land Development. No. 31 p. 129-137. DOI: 10.1515/jwld-2016-0044.

\begin{abstract}
Soil erosion by water and the impact of sediment transport on lakes and streams, can seriously degrade soil and create problems for both agricultural land and water quality. The present study has been carried out to assess suspended sediment yield in Mellegue catchment, northeast of Algeria. Regression analysis was used to establish a relationship between the instantaneous water discharge $(Q)$ and the instantaneous suspended sediment concentration $(C)$ based on all recorded data and seasonal ratings for the period 1970-2003. The regression technique used in this paper involved a division of data into discharge - based classes, the mean concentrations and discharges of which are used to develop power regressions, according to single and season ratings, through logtransformation. Sediment loads estimated by stratified rating curves reduced underestimations to a range from 2 to $4 \%$. The mean annual sediment yield during the 34 years of the study period was $589.23 \mathrm{t} \cdot \mathrm{km}^{-2} \cdot \mathrm{y}^{-1}$. Sediment transport is dominated by fall rainstorms accounting for $41 \%$ of the annual load. The big supply of sediment during this season confirms the intense geomorphic work by fall storms caused by high intensity rainfall and low vegetation cover.
\end{abstract}

Key words: erosion, Mellegue watershed, sediment rating curves, sediment transport, suspended sediment concentration

\section{INTRODUCTION}

Soil erosion remains the world's biggest environmental problem that has caused many issues involving land degradation, silting of waterways, ecological degradation, and nonpoint source pollution. Therefore, it is significant to understand the processes of soil erosion and sediment transport along rivers, and this can help identify the erosion prone areas and find potential measures to alleviate the environmental effects [WU, CHEN 2012].

In Algeria, especially in semiarid areas the seasonality of hydrological processes and the strong interannual variation in precipitation rates enhance the role of infrequent flood events [SOLER et al. 2007]. In these areas suspended sediment transport is causing problems for water-resource management where channels are impounded as high rates of sedimentation occur in reservoirs. Consequently, the need to quantify and estimate the amount of erosion and sediment yields has become essential at watershed scale and in the implementation of conservation efforts.

In the recent past, several studies focused on the phenomenon of erosion in rivers, where sediment transport estimates have been evaluated over time and space [ACHITE 2002; ACHITE, MEDDI 2005; BENKHALED, REMINI 2003; DEMMAK 1982; ElAHCENE, REMINI 2009; KHANCHOUL et al. 2007; 2009; 2012; LAHLOU 1990; MEDDI 1999; MEGNOUNIF et al. 2003; Probst, Amiotte Suchet 1992; Shah-FAIRBANK, JULIEN 2015; SNOUSSI et al. 1990; TERFOUS et al. 2001]. A description of other studies undertaken in semiarid watersheds is given in Table 1 . 
Sediment yield from a catchment is an integrated result of all water erosion and transport processes occurring in the entire contributing area [LANE et al. 2000]. For the different gauged systems, suspended sediment yield was computed from rating curves established from different periodterm measurement series [FERGUSON 1986; KHANCHOUL et al. 2009; WALLING 1977]. The suspended sediment rating curve or transport curve is usually presented in one of two basic forms, either as a suspended sediment concentration/streamflow or as a suspended sediment discharge/streamflow relationship [WALLING 1977]. In both cases a logarithmic plot is commonly used, with Ordinary Least Squares (OLS) regression employed to fit a straight line through the scatter of points [WALLING 1977]. In most cases, rating curves are constructed from instantaneous observations of discharge and either sediment concentration or load.

This paper provides holistic assessment of the fluvial sediment input to Mellegue watershed by means of analysing largely existing sediment discharge data on the Mellegue River. The objectives of this study are: (1) to investigate the changes in monthly streamflow and sediment load regime and their relationship using long-term observations along the study river; (2) to analyze potential influencing factors on suspended sediment load changes such as lithology, land use, soil and water conservation measures and other human activities.

Table 1. Basins monitored in semiarid environments

\begin{tabular}{|l|c|c|c|}
\hline \multicolumn{1}{|c|}{ Reference } & River basin & $\begin{array}{c}\text { Basin area } \\
\mathrm{km}^{2}\end{array}$ & $\begin{array}{c}\text { Sediment } \\
\mathrm{yield} \\
\mathrm{t} \cdot \mathrm{km}^{-2} \cdot \mathrm{y}^{-1}\end{array}$ \\
\hline ACHITE, OUILLON 2007 & Abd, Algeria & 2480 & 136 \\
\hline KHANCHOUL et al. 2012 & Cherf, Algeria & 1710 & 350 \\
\hline ELAHCENE et al. 2013 & Bellah, Algeria & 55 & 610 \\
\hline $\begin{array}{l}\text { MADANICHERIF } \text { et al. } \\
2012\end{array}$ & Taria, Algeria & 1365 & 236 \\
\hline $\begin{array}{l}\text { LÓPEZ-TARAZÓN } \text { et al. } \\
2011\end{array}$ & Isábena, Spain & 445 & 527 \\
\hline MEGNOUNIF et al. 2007 & Sebdou, Algeria & 256 & 1047 \\
\hline TOUABIA, GHENIM 2011 & K'sob, Algeria & 1480 & - \\
\hline FANDI et al. 2009 & Sikkak, Algeria & 218 & 170 \\
\hline GHENIM et al. 2008 & Mouilah, Algerie & 2650 & 165.3 \\
\hline
\end{tabular}

Source: own elaboration.

\section{DATA AND METHODOLOGY}

\section{STUDY AREA}

The present Mellegue catchment belongs to the Medjerda Basin $\left(7847 \mathrm{~km}^{2}\right)$ and is located in the extreme Northeast of Algeria. It drains an area of 4570 $\mathrm{km}^{2}$ for a perimeter of $613 \mathrm{~km}$ at the gauging station Ouenza. This station, controlled by the National Agency of Hydraulic Resources (ANRH), is an outlet of the study Mellegue basin, from where water discharge and suspended sediment concentration data are collected (Fig. 1). The main physiographic characteristics are reported in Table 2.

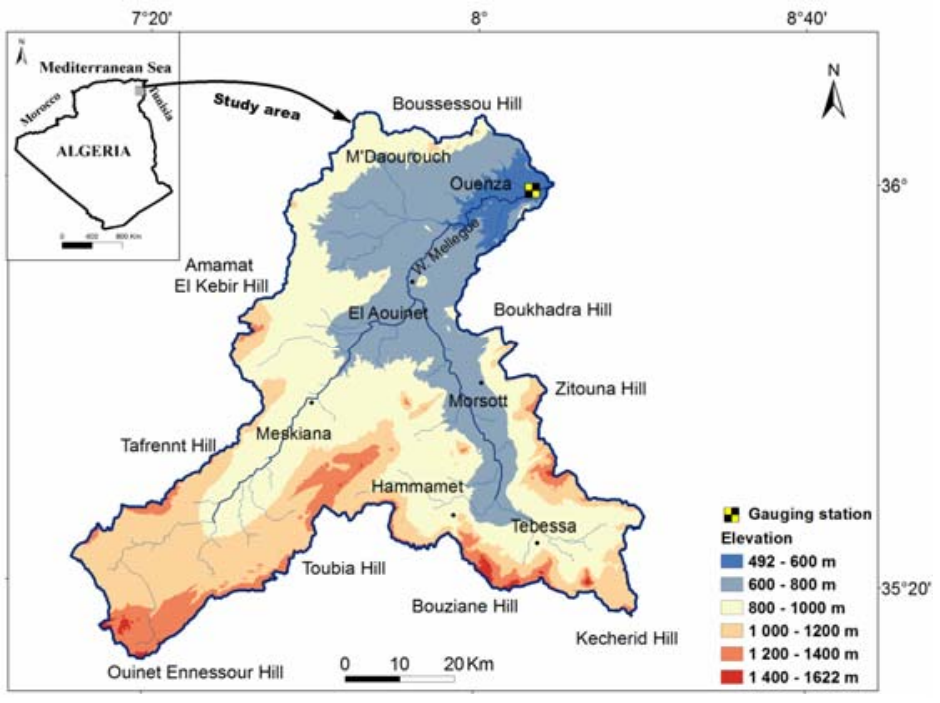

Fig. 1. Location map of the study area; source: own elaboration
Table 2. Main characteristics of the study catchment

\begin{tabular}{|l|c|c|}
\hline \multicolumn{1}{|c|}{ Parameters } & Unit & Value \\
\hline Basin area & $\mathrm{km}^{2}$ & 4575 \\
\hline Perimeter & $\mathrm{km}$ & 615 \\
\hline Mean elevation & $\mathrm{m}$ & 916 \\
\hline Minimum elevation & $\mathrm{m}$ & 492 \\
\hline Maximum elevation & $\mathrm{m}$ & 1622 \\
\hline Compactness coefficient & - & 2.94 \\
\hline Mean basin slope & $\%$ & 4 \\
\hline Length of the main wadi & $\mathrm{km}$ & 163 \\
\hline Drainage density & $\mathrm{km} \cdot \mathrm{km}^{-2}$ & 1.22 \\
\hline
\end{tabular}

Source: own elaboration based on ArcGIS 2010.

The climate over the study basin is semiarid, with dry summers and rainfalls concentrated mainly in fall and spring periods. The average annual rainfall is equal to $270 \mathrm{~mm}$ and is recorded at the Ouenza rainfall station from 1970 to 2011 with an abundant rainfall occurring from March to May (mean values ranging from 28.7 to $37.9 \mathrm{~mm}$ ) and the mean annual temperature is about $16^{\circ} \mathrm{C}$. The precipitation data at the Ouenza station shows that there are rainfall events greater than $40 \mathrm{~mm} \cdot$ day $^{-1}$ recorded mainly in September, October, April and May and the highest rainfall intensity is recorded in May $\left(61.3 \mathrm{~mm} \cdot \mathrm{day}^{-1}\right)$. The elevation of the basin varies between 1622 and $492 \mathrm{~m}$.

More than $45 \%$ of its area is covered by calcareous crusts and weathered limestone, which occupy almost all the western part of the catchment. Cretaceous marl and quaternary deposits, which represent the most erodible lithologic formations cover $27 \%$ of the basin area (Fig. 2). The landscape formed on predominantly resistant rocks including sandstone, Aptian limestone and limestone associated with dolomite cover $12.5 \%, 6.5 \%$ and $2.3 \%$, respectively, and are located in the southeastern part of the Mellegue basin. 


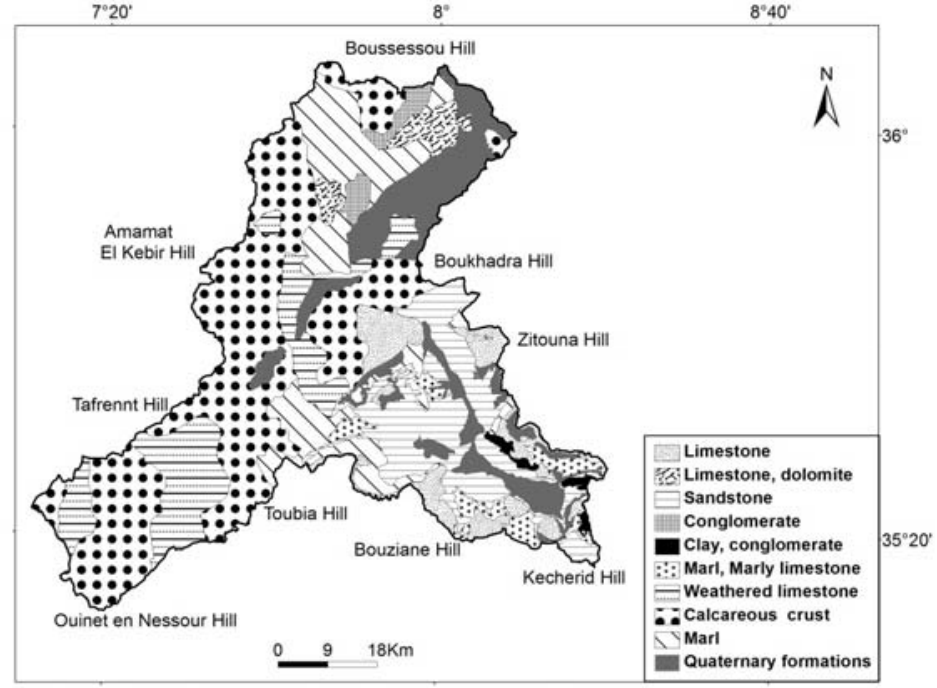

Fig. 2. Lithologic map of the Mellegue catchment; source: own elaboration

Slope gradient and vegetation cover are two factors of great significance for the erosion intensity. More than $60 \%$ of the basin has slopes with gradients lesser than $3^{\circ}$. About $5 \%$ of the basin area has slopes $>15^{\circ}$ that occupy the south-eastern part of the basin dominated by resistant and moderately resistant outcrops (limestone, marly limestone and marl).

For the most part, the basin is composed of poorly developed soils (alluvium, loam) that represent $40 \%$ of the total basin area and are located in the south-eastern and south-western part of the Mellegue catchment. About $28.6 \%$ of the study basin is occupied by marl-clayey soil distributed in the northeastern and south-eastern part of the Mellegue River basin.

In the study catchment, more than $30 \%$ of the basin area is agricultural land with cereals. Steppes and grasslands cover $26 \%$ of this zone. Dense forests of Alep trees are rare because of the frequent fires in

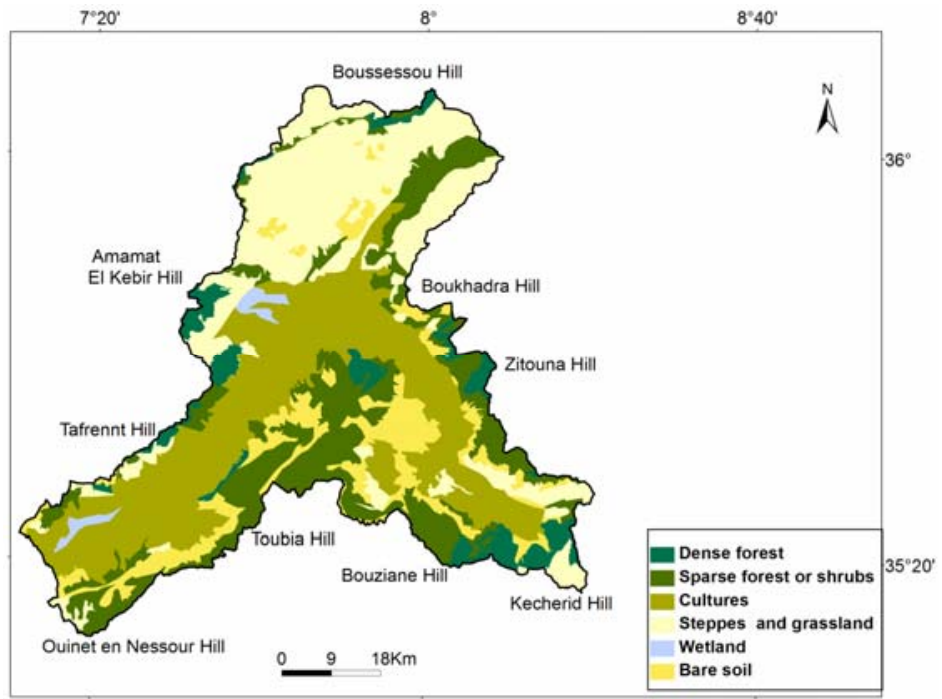

Fig. 3. Land use map of the Mellegue catchment; source: own elaboration summer and the forest areas are generally more open, with bare soils exposed to erosion. Open forest and shrubs cover $22 \%$ of the Mellegue catchment (Fig. 3).

\section{SUSPENDED SEDIMENT SAMPLING}

The collection of the hydro-climatic data and suspended sediment concentrations during a thirty-four-year period (1970/1971 to $2003 / 2004$ ) was possible due to collaboration of different services of the National Agency of Hydraulic Resources (ANRH) of Tebessa, Constantine and Algiers. The Ouenza hydrometric dataset included:

1) instantaneous discrete data of suspended sediment concentration $(C)$ and corresponding water discharge $(Q)$;

2) records of daily water discharge, and

3) instantaneous water discharge during storm events.

The discharges $\left(Q, \mathrm{~m}^{3} \cdot \mathrm{s}^{-1}\right)$ are directly referred by the rating curve to the heights of water measured by a limnimetric ladder and floating water level recorder. With each flow measurement, water samples were taken close to the bank of the river to determine suspended sediment concentration. The water samples were filtered through $145 \mu \mathrm{m}$ filter paper. The sediment collected was weighed after drying at $105^{\circ} \mathrm{C}$ for 24 hours: the difference in weight of the filter before and after filtration enabled the suspended sediment concentration to be calculated given the volume of water filtered $\left(C, \mathrm{~g} \cdot \mathrm{dm}^{-3}\right)$. The number of samples was adapted to the hydrological regime. They were taken every other day or, during flood periods, as frequently as every half-hour [MEGNOUNIF et al. 2007].

\section{APPLICATION OF THE SEDIMENT RATING CURVE}

Once sufficient data were collected, attention was given to derive the rating relationship. The data set used to develop the sediment rating curve of Wadi Mellegue consisted of 2602 measurements of instantaneous suspended sediment concentration, and the corresponding water discharges. Regression analysis was used to establish a relationship between the instantaneous concentration $(C)$ and the instantaneous water discharge $(Q)$. The most commonly used sediment rating curves is a power function [JANSSON 1997; WALLING 1987], written as follows:

$$
C=a Q^{b}
$$

where $a$ and $b$ are regression coefficients.

Although the accuracy of this approach was questioned by WALLING 
[1977], the applicability appears to be adequate for many purposes (e.g., CRAWFORD [1991]). It was demonstrated that improvement of the log-transformation regression formulation can significantly reduce the bias introduced in the calculation [COHN 1995; COHN et al. 1989].

Regression analysis of the $C-Q$ relationship provided a fairly low coefficient of correlation $(r=0.76)$ and the data showed a scatter distribution mainly at low and medium values. The developed regression on all separate measurements overestimated the true sediment load by $57 \%$ when calculated from all 2602 data. Due to this overestimation of sediment load, a further technique about the suspended sediment load estimation should be provided.

The procedure of getting significant sediment estimates started by sorting the data that include measured values, and by regrouping them into distinct classes of water discharge. The definition of the width of each class interval depends on the data base in question. The mean sediment concentration of the measurements in every class was computed and entered in a plot to determine the change in direction of the sediment rating curve and to check the goodness of fit of the developed regression [KHANCHOUL et al. 2007]. It is possible that a sediment rating curve consists of one or two regression curves with breakpoints determined by the changes in inclination of the imagined line through the class means. The discharge of the change in inclination of the rating curve may be regarded as a threshold discharge of the sediment concentration [KHANCHOUL et al. 2009].

An attempt was also made to subdivide the dataset into seasons as winter, spring, summer and fall periods to show the importance of seasons in the understanding of hydrological phenomena in this basin of a semiarid climate and to check the goodness of fit of the regression curves.

As log-transformation of the means was used to develop the regression equations, the re-transformed equations were corrected for bias. MILLER [1984] proposed a correction factor $(C F)$ of a regression of natural logarithms. This factor is defined by the following formula:

$$
\begin{gathered}
C F=\exp \left(0.5 \sigma^{2}\right), \\
\sigma^{2}=1 /(N-1) \cdot \sum\left(\ln C_{i}-\ln C^{\prime}{ }_{i}\right)^{2}
\end{gathered}
$$

where $\sigma^{2}, C_{i}$ and $C^{\prime}{ }_{i}$ are the variance of natural logarithms, the measured and estimated concentration respectively.

The corrected equation assumes a form:

$$
C=C F \cdot a Q^{b}
$$

Errors were calculated and expressed as a percentage of the value calculated from the "measured" data as follows:

$$
\text { Error }(\%)=\left(\frac{\text { continuousrecordload }}{\text { rating curveestimate }}-1\right) \cdot 100
$$

\section{RESULTS AND DISCUSSION}

\section{RELIABILITY OF THE RATING RELATIONSHIPS}

The sediment rating curves developed using instantaneous $C-Q$ for all available data from Ouenza hydrometric station were illustrated in Figure 4 . When only one regression was developed for all the means, the rating curve did not fit the means at high and at low discharges. It is important for high discharges to be accurately represented because the majority of the suspended sediment is transported during high storm events. Meanwhile, the stratified rating has shown a better fit and lesser scatter of points around the regression lines. The best-fit power function line through the data for the stratified rating gave a fairly low and moderate coefficients of correlation $(r=0.62$ and 0.84$)$.

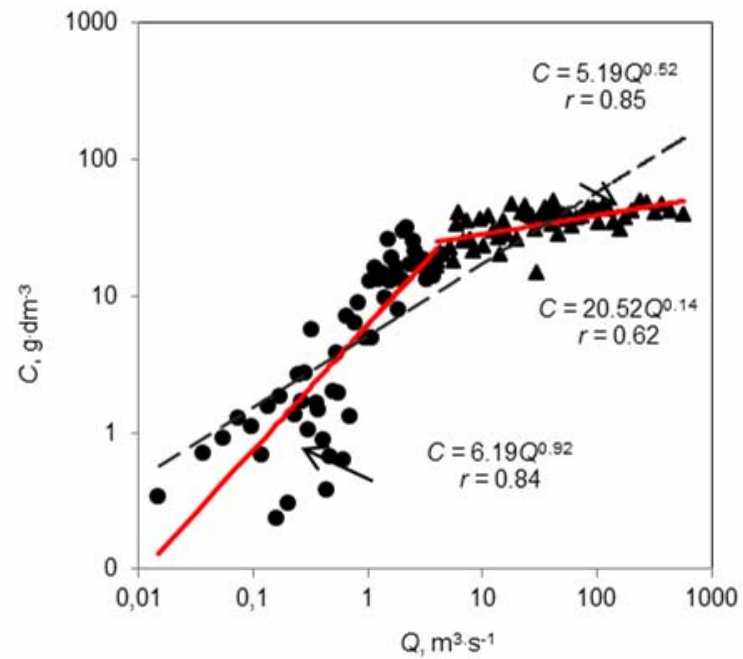

Fig. 4. The single ratings developed from instantaneous concentration and instantaneous water discharge; source: own study

The data that were grouped according to seasons are given in Figure 5. Thus, dividing the data into different flow regimes created stratified rating curves. The divisions were chosen somewhat arbitrarily based on the apparent changes in the slope of the rating curves. The use of the discharge class technique to develop sediment rating curves provided good results. The regression functions for the season ratings provided coefficients of correlation ranging from 0.55 to 0.94 .

Rating curves developed for all means, means during different seasons showed interesting correlation coefficients. However, we need to compute sediment loads to be able to provide an accurate estimate approaching the measured sediment load. Thus, the sum of suspended sediment loads calculated from concentrations from various rating curve equations were compared with the loads calculated from the measured concentrations (Tab. 3).

The errors mentioned in Table 3 demonstrated that sediment loads calculated by using a stratified 

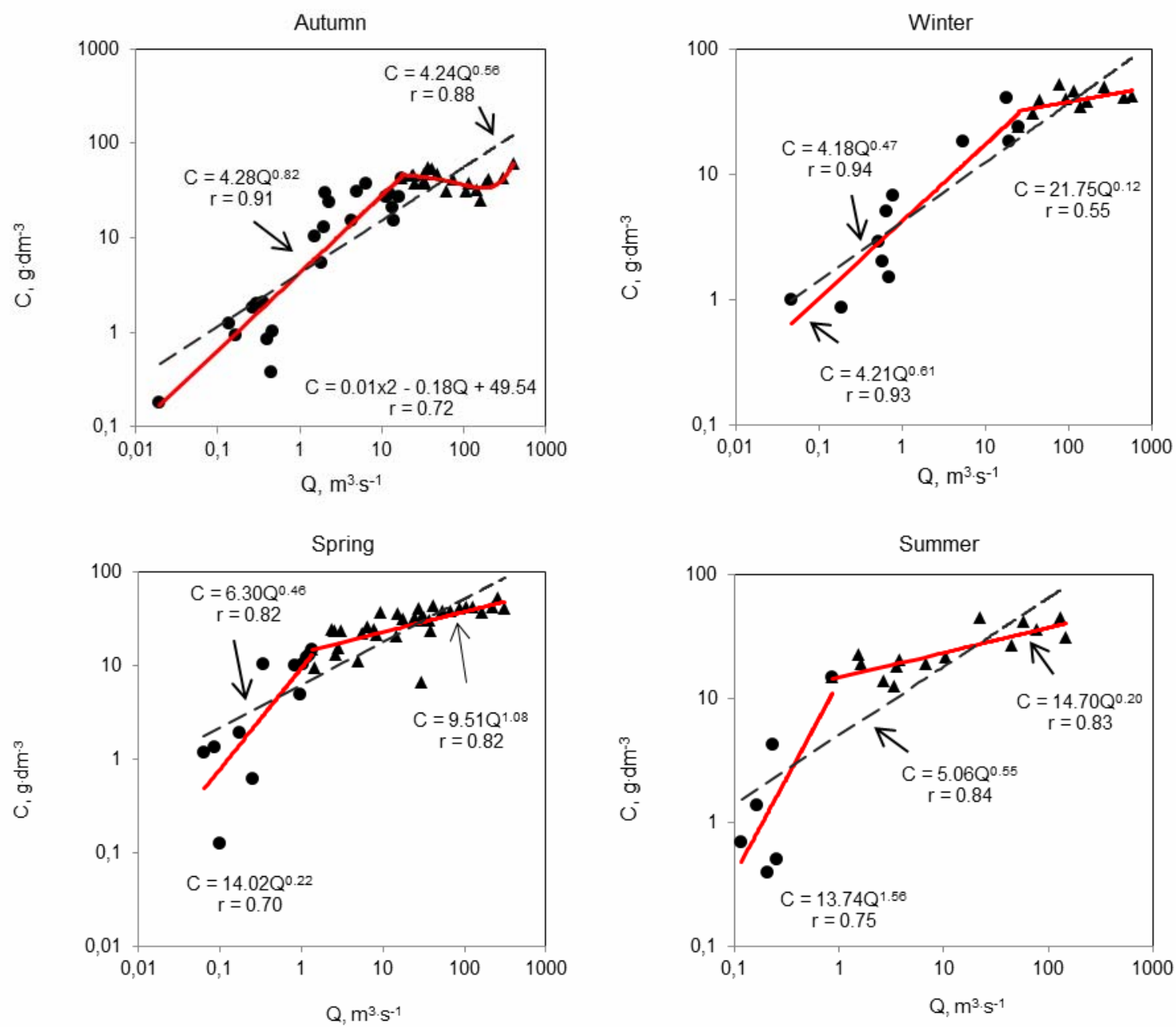

Fig. 5. Sediment rating curves developed from instantaneous water discharge $(Q)$ and instantaneous concentration $(C)$ for different seasons; source: own study

Table 3. Sediment load calculated for the single and seasonal sediment rating curve method

\begin{tabular}{|c|c|c|c|c|c|c|}
\hline \multicolumn{2}{|c|}{ Sediment load (SL) } & $\mathrm{N}$ & $\mathrm{SL} \cdot 10^{3}$ tonnes & $\begin{array}{c}\text { Error } \\
\%\end{array}$ & $\begin{array}{c}\text { Corrected } \\
\mathrm{SL} \cdot 10^{3} \text { tonnes } \\
\end{array}$ & $\begin{array}{c}\text { Error } \\
\%\end{array}$ \\
\hline \multicolumn{2}{|c|}{ Continuous concentration record } & 2602 & 3785.78 & & & \\
\hline \multirow{2}{*}{ Single rating: } & one regression line & & 7241.62 & +91.28 & - & - \\
\hline & two regression lines & & 3948.59 & +4.30 & - & - \\
\hline \multicolumn{3}{|l|}{ Seasonal ratings: } & 3862.85 & +2.00 & - & - \\
\hline Autumn season & $\begin{array}{l}\text { one regression line } \\
\text { two regression lines }\end{array}$ & 894 & $\begin{array}{l}2529.11 \\
1387.42\end{array}$ & $\begin{array}{l}+77.10 \\
-2.85\end{array}$ & $\begin{array}{c}- \\
1409.25\end{array}$ & $\begin{array}{c}- \\
-1.32\end{array}$ \\
\hline Winter season & $\begin{array}{l}\text { one regression line } \\
\text { two regression lines }\end{array}$ & 391 & $\begin{array}{r}1405.05 \\
986.05\end{array}$ & $\begin{array}{l}+46.14 \\
+2.56\end{array}$ & $\begin{array}{l}- \\
-\end{array}$ & $\begin{array}{l}- \\
-\end{array}$ \\
\hline Spring season & $\begin{array}{l}\text { one regression line } \\
\text { two regression lines }\end{array}$ & 950 & $\begin{array}{l}1861.36 \\
1273.16 \\
\end{array}$ & $\begin{array}{l}+42.15 \\
-2.77 \\
\end{array}$ & $\begin{array}{c}- \\
1273.74 \\
\end{array}$ & -2.73 \\
\hline Summer season & $\begin{array}{l}\text { one regression line } \\
\text { two regression lines }\end{array}$ & 367 & $\begin{array}{l}353.16 \\
216.22 \\
\end{array}$ & $\begin{array}{l}+60.31 \\
-1.85 \\
\end{array}$ & $\begin{array}{c}- \\
222.49\end{array}$ & $\begin{array}{c}- \\
+0.99 \\
\end{array}$ \\
\hline
\end{tabular}

Source: own study.

rating curve for instantaneous values without seasonal division overestimated the load by $4.3 \%$, and the seasonal ratings overestimated the load by only $2 \%$. From among different calculations, the use of seasonal sediment rating curve gave satisfactory results.

Thus, the application of logged mean values in discharge classes for developing rating curves, often consisting of more than one regression, gave low er- rors in load estimates, especially the season-distinguished rating curves.

\section{MONTHLY AND ANNUAL VARIATION OF SUSPENDED SEDIMENT LOAD}

Based on the seasonal sediment rating curve, the calculated mean annual suspended sediment yield in 
the Mellegue basin during the period 1970/1971$2003 / 2004$ was equal to $589.23 \mathrm{t} \cdot \mathrm{km}^{-2} \cdot \mathrm{y}^{-1}$, which corresponded to an annual sediment load of $91.67 \cdot 10^{6}$ tonnes (Tab. 4).

Table 4. Seasonal suspended sediment load variation in the Mellegue basin

\begin{tabular}{|l|c|c|c|c|c|}
\hline \multirow{2}{*}{\multicolumn{1}{|c|}{ Parameter }} & \multicolumn{5}{c|}{ Value in season } \\
\cline { 2 - 6 } & autumn & winter & spring & summer & year \\
\hline Sediment load, $10^{6} \mathrm{t}$ & 37.54 & 13.62 & 25.99 & 14.52 & 91.67 \\
\hline $\begin{array}{l}\text { Sediment yield, } \\
\mathrm{t} \cdot \mathrm{km}^{-2} \cdot \mathrm{y}^{-1}\end{array}$ & 241.32 & 87.56 & 167.05 & 93.30 & 589.23 \\
\hline $\begin{array}{l}\text { Mean concentration, } \\
\mathrm{g} \cdot \mathrm{dm}^{-3}\end{array}$ & 24.34 & 19.58 & 22.40 & 19.95 & 21.57 \\
\hline $\begin{array}{l}\text { Mean water dis- } \\
\text { charge }, \mathrm{m}^{3} \cdot \mathrm{s}^{-1}\end{array}$ & 4.04 & 1.81 & 3.01 & 1.86 & 2.68 \\
\hline
\end{tabular}

Source: own study.

The study of seasonal distribution of sediment load has indicated that $37.54 \cdot 10^{6}$ tonnes were transported during the autumn. This quantity represents $41 \%$ of the total sediment load. The second highest sediment load occurred during the spring with a load reaching $26 \cdot 10^{6}$ tonnes, which represent $29 \%$ of the total load. This seasonal variability can be explained by the fact, that in autumn the floods are more intensive than the floods in spring. The high variability in rainfall is also responsible for the changes in vegetation that in turn directly influence the erosive capacity of rainfall [ACHITE, OUILLON 2007]. Sediment transport thus occurs mainly in autumn after long dry seasons characterized by high temperatures, by destruction of ground aggregates, and by reduction of vegetation cover [RAKOCZI 1981]. The suspended sediment load of the autumn months is higher in September with $554.40 \cdot 10^{3}$ tonnes, which is mainly a reflection of the rise of rainstorms, runoff and sediment concentration during storm events. The storm event of 29-30 September 1986 shows that $Q$ and $C$ had simultaneous peaks with one small concentration rise on the falling limb and one at the end of the hydrograph. After almost $48 \mathrm{~h}$ of the storm event, the total rains of $25 \mathrm{~mm}$ had provided a high water discharge of 262 $\mathrm{m}^{3} \cdot \mathrm{s}^{-1}$ and a peak sediment concentration of $88 \mathrm{~g} \cdot \mathrm{dm}^{-3}$ (Fig. 6a). In 09-10 September 1999, after almost $48 \mathrm{~h}$ of the storm event. The main $C$ peak shows a concentration as high as $109 \mathrm{~g} \cdot \mathrm{dm}^{-3}$, with a maximum discharge of $332 \mathrm{~m}^{3} \cdot \mathrm{s}^{-1}$ and a total rainfall of $77 \mathrm{~mm}$. The $Q$ and $C$ curves show simultaneous peaks (Fig. 6b).

The suspended sediment load values during the study period were higher in 1972/1973, 1989/1990, $1995 / 1996$ and $1999 / 2000$ with $6.4 \cdot 10^{6}$ tonnes, $5.7 \cdot 10^{6}$ tonnes, $10.8 \cdot 10^{6}$ tonnes and $5.7 \cdot 10^{6}$ tonnes respectively (Fig. 7). The highest sediment concentration value was recorded on 30 May 1989 with $521.70 \mathrm{~g} \cdot \mathrm{dm}^{-3}$ corresponding to a mean water discharge of $1.50 \mathrm{~m}^{3} \cdot \mathrm{s}^{-1}$.

A possible explanation for the considerable higher sediment yield in the Mellegue catchment is in the fact that morphological factors (e.g., rainfall intensity and land use) coupled with the dominant weak
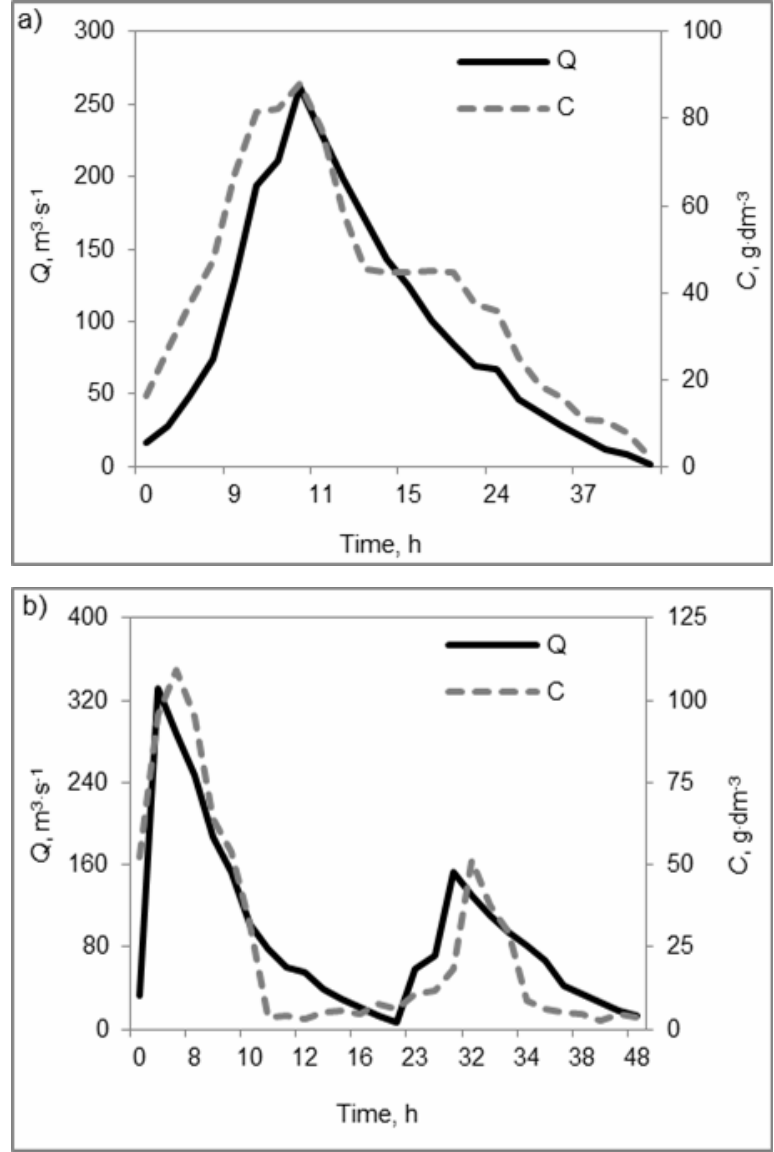

Fig. 6. Examples of flood events in the autumn: a) 29-30.09.1986, b) 09-10.09.1999; source: own study

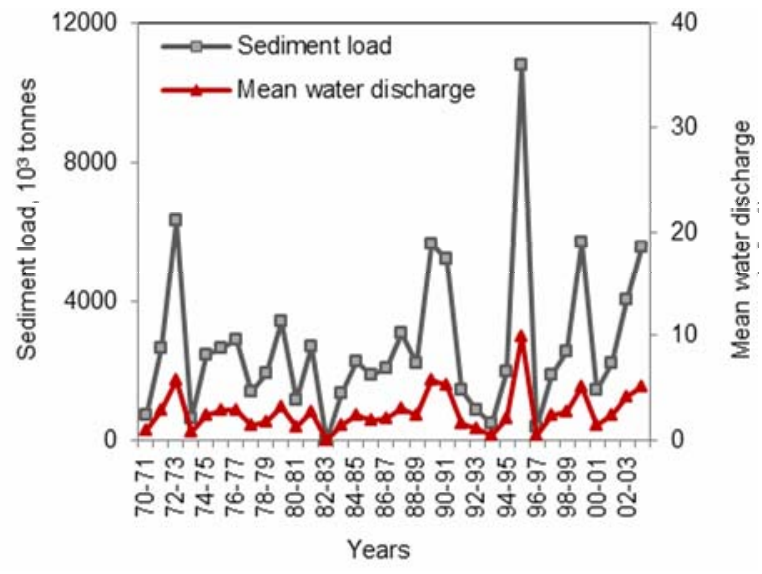

Fig. 7. Annual suspended sediment load variation in the Mellegue basin; source: own study

geological layers and topography acted as additional forces to sediment availability within the catchment. High sediment yields in semiarid environments can be explained in terms of interaction between erosive energy and vegetation density even if climatic seasonality, relief, basin lithology and the extent of human activity combine to influence the global pattern of erosion processes [WOLMAN, GERSON 1978].

The high erosion in the Mellegue Basin can also be due to agricultural expansion and overgrazing in open shrubland and pasture, with consequently low 
vegetation cover during the winter. As a consequence, surface runoff is facilitated and the sediment is not stopped by any vegetation cover, and thus the delivery to streams and by streams is high.

Sustainable land management practices are urgently required to reduce erosion rates of soils located mainly in the north-eastern part of the Mellegue River basin in order to increase soil productivity and the global stock of productive agricultural land.

Agricultural activities and irrigational practices should continue with improvements through terracing, practicing crop rotation, improved agro-forestry practices. Reforestation with Alep trees provides protection against scouring and minimizes the erosion risk by reducing flow velocity.

\section{CONCLUSION}

Soil erosion constitutes a major aspect of degradation of the landscapes in the semiarid Mediterranean environments. The prevailing climatic and other geomorphic conditions had certainly significant control over the water flux and suspended sediment load patterns in the Mellegue River. The estimation of suspended sediment load in the Mellegue basin using least square regression on log-transformed means in discharge classes produced satisfactory results.

The load calculated with one single regression on all the means overestimated the load by $91.28 \%$. The rating curve that has been divided into more than one regression to fit the means produced more accurate loads, where the regression lines between discharge thresholds overestimated sediment load by about $4 \%$ and $2 \%$ compared with the load from measured concentrations according to single and seasonal ratings respectively.

Suspended sediment load during the fall season accounted for $41 \%$ of the total suspended sediment supplied by the river during the 34-year period and is caused by the impact of heavy rainstorms during a season with fairly low vegetation cover, and by the fact that the eroded material is easily supplied to Meskiana and Morsott tributaries due to fairly steep slopes. In this season there are also shallow landslides and channel erosion that occur mainly on clayey soils and weak rocks. The load was highest in September. Despite high discharges in spring, sediment loads failed to rise to the loads observed in the fall, because of more vegetation cover in spring and less machine activity in the fields.

Quantitative assessment by the sediment rating curve indicated that the mean sediment yield for the catchment area was about $589.23 \mathrm{t} \cdot \mathrm{km}^{-2} \cdot$ year $^{-1}$. The annual loads and the annual mean concentrations varied substantially between years.

For that purpose, sustainable management of water and soil resources requires effective use of predictive models and an ability to analyze the data in the context of high temporal variability of semiarid environments.

\section{REFERENCES}

ACHITE M., MedDi M. 2005. Variabilitéspatio-temporelle des apportsliquideetsolideen zone semi-aride: Cas du bassin versant de l'oued Mina (Nord-Ouestalgérien) [Spatio-temporal variability of liquid and solid contributions in semiarid area: a case study of Wadi Mina catchment (North-West of Algeria)]. Revue dessciences de l'eau. Vol. 18 p. 37-56.

ACHITE M., OUILlon S. 2007. Suspended sediment transport in a semiarid watershed, Wadi Abd, Algeria (19731995). Journal of Hydrology. Vol. 343 p. 187-202.

BenKHAlED A., Remini B. 2003. Variabilité temporelle de la concentration en sediments et phénomènes d'hystérésisdans le bassin de l'Oued Wahrane (Algérie) [Temporal variability of sediment concentration and hysteresis phenomena in the Wadi Wahrane Basin (Algeria)]. Hydrology Science Journal. Vol. 48. No. 2 p. 243-255.

CoHN T.A. 1995. Recent advances in statistical methods for the estimation of sediment and nutrient transport in rivers. Reviews of Geophysics. Vol. 33. No. 1 p. $1117-$ 1123.

Cohn T.A., Delong L.L., Gilroy E.J., Hirsch R.M., WeLLS D.K. 1989. Estimating constituent loads. Water Resources Research. Vol. 25. No. 5 p. 937-942.

CRAWFORD C.G. 1991. Estimation of suspended sediment rating curves and mean suspended sediment loads. Journal of Hydrology. Vol. 129 p. 331-348.

Demmak A. 1982. Contribution à l'étude de l'érosionet des transports solidesen Algérie Septentrionale [Contribution to the study of erosion and sediment transport in Algeria]. PhD Thesis. Paris. Université de Pierre et Marie Curie pp. 323.

ElahCENe O., ReminiB. 2009. Corrélation entre la concentration en matière en suspension et le débit liquide dans le bassin versant de l'oued Bellah (Algérie) [Correlation between suspended sediment concentration and water discharge in the Wadi Bellah Watershed (Algeria)]. European Journal of Scientific Research. Vol. 26 p. 139-46.

Elahcene O., Terfous A., Remini B., GhenaimA., Poulet J.B. 2013. Etude de la dynamique sédimentaire dans le bassin versant de l'Oued Bellah (Algérie) [Study of sediment dynamics in the Wadi Bellah catchment (Algeria)]. Hydrological Sciences Journal. Vol. 58. No. 1 p. $1-13$.

Fandi O., Bouanani A., Babahamed K., Bekkouche A. 2009. Modélisation du transport des particules du sol en suspension dans l'oued Sikkak, Nord Ouest Algérien [Transport modeling of suspended soil particles in Wadi Sikkak, North West of Algeria]. Colloque international sols non saturés et Environnement. 27-28 October 2009, Tlemcen (Algeria).

FERGUSON R.I. 1986. River loads underestimated by rating curves. Water Resources Research. Vol. 22 p. 74-76.

GHENIM A., SEDdini A., Terfous A. 2008. Variation temporelle de la dégradation spécifique du bassin versant de l'Oued Mouilah, Nord-Ouest algérien [Temporal variation in specific degradation of the Wadi Mouilah watershed, Northwest Algeria. Hydrological Sciences Journal. Vol. 53. No. 2 p. 448-456. DOI: 10.1623/hysj.53.2.448.

JANSSON M.B. 1997. Comparison of sediment rating curves developed on load and on concentration. Nordic Hydrology. Vol. 28. No. 3 p. 189-200. 
Khanchoul K., Altschul R., Assassi F. 2009. Estimating suspended sediment yield, sedimentation controls and impacts in the Mellah Catchment of Northern Algeria, Arabian Journal of Geosciences. DOI: 10.1007/s12517009-0040-6.

KhANCHOUl K., BouKhrissa Z.E., MAJOUR H. 2012. Statistical modelling of suspended sediment transport in the Cherf drainage basin, Algeria. Comunicações Geológicas. Vol. 99 . No. 1 p. 27-32.

Khanchoul K., Jansson M.B., LANGe Y. 2007. Comparison of suspended sediment yield in two catchments, Northeast Algeria. Zeitschrift für Geomorphologie. Vol. 51. No. 1 p. 63-94.

LAHLOU A. 1990. Modèles de prédiction de la sédimentation des retenues de barrages des pays du grand Maghreb. In: Atelier International Tunis: UNESCO-AISH-ENIT sur l'application des modèles mathématiques à l'évaluation des modifications de la qualité des eaux [Predictive models of dam reservoirs sedimentation of the Maghreb countries. In: The application of mathematical models for the assessment of changes in water quality] p. 312 324.

LANe L.J., Kidwell M.R., Weltz M.A. 2000. Watershed sediment yield and rangeland health. International Journal of Sediment Research. Vol. 15. No. 1 p. 51-59.

López-TARazón J.A., BATAlla R.G., Vericat D., Francke T. 2012. The sediment budget of a highly dynamic mesoscale catchment: The River Isábena. Geomorphology. Vol. 138. Iss. 1 p. 15-28. DOI: 10.1016/ j.geomorph.2011.08.020.

Madani Cherif H., Terfous A., Bouanani A., Ghenaim A. 2012. Variablity of streamflow and sediment yields in wadi Taria (Northwest Algeria). Sixteenth International Water Technology Conference. IWTC 16 2012, Istanbul (Turkey) p. 1-15.

MedDI M. 1999. Etude du transport solide dans le basin versant de l'Oued Ebda Algérie [Sediment transport study in the Wadi Ebda catchment Algeria]. Zeitschrift fûr Geomorphologie. Vol. 43 p. 167-183.

Megnounif A., Terfous A., Bouanani A. 2003. Production and transport of suspended sediment transport in the Upper-Tafna river basin (North West Algeria). Revue des Sciences de l'Eau. Vol. 16. No. 3 p. $369-380$.

Megnounif A., Terfous A., Ghenaim A., Poulet J.B. 2007. Key processes influencing erosion and sediment transport in a semiarid Mediterranean area: the Upper Tafna catchment, Algeria. Hydrological Sciences Journal. Vol. 52. No. 6 p. 1271-1284. DOI: $10.1623 /$ hysj.52.6.1271.

MiLLER D.M. 1984. Reducing transformation bias in curve fitting. American Statistical Association. Vol. 38. No. 2 p. $124-126$
Probst J.L., Amiotte Suchet P. 1992. Fluvial suspended sediment transport and mechanical erosion in the Maghreb. Hydrological Sciences Journal. Vol. 37. No. 6 p. 621-637.

RAKOCZI L. 1981. Problems of sediment gauging in gravel bed rivers. International Association for Hydraulic Research XIX Congress, New Delhi, India.

SHAH FAIRBANK S.C., JULIEN P.Y. 2015. Sediment load calculations from point measurements in sand-bed Rivers. International Journal of Sediment Research. Nr 30 p. 112.

Snoussi M., Jouanneau J.M., Latouch C. 1990. Flux de matières issus de bassins versants des zones semi-arides (bassins du Sebou et du Souss, Maroc). Importance dans le bilan global des apports d'origine continentale parvenant à l'océan Mondial [Material flows from watersheds in semiarid areas (basins of Sebou and Souss, Morocco). Importance in the overall balance of continental origin inflows reaching the World Ocean]. Journal of African Earth Sciences. Vol. 11. Iss. 1-2 p. $43-54$.

Soler M., Regüés D., Latro J., Gallart F. 2007. Frequency-magnitude relationships for precipitation, stream flow and sediment load events in a small Mediterranean basin (Vallcebre basin, Eastern Pyrenees). Catena. Vol. 71 p. 164-171.

Terfous A., Megnounif A., Bounanani A. 2001. Etude du transport solide en suspension dans l'oued Mouilah (Nord-Ouest Algérien) [Study of suspended sediment transport in the Mouilah drainage basin (North West Algeria)]. Revue des Sciences de l'Eau. Vol. 14. No. 2 p. $175-187$.

TOUAIBIA B., GHENIM A.N. 2011. Estimation of the bias of the regression power model "concentration-discharge» in K'sob basin. Revue Scientifique et Technique. Vol. 46. No. 1 p. 41-53.

WALLING D.E. 1977. Assessing the accuracy of suspended sediment rating curves for a small basin. Water Resources Research. Vol. 13. No. 3 p. 531-538. DOI: 10.1029/WR013i003p00531.

WaLLING D.E., WeBB B.W. 1987. Suspended load in gravelbed rivers: UK experience. In: sediment transport in gravel-bed rivers. Ed. C.R. Thorne, J.C. Bathurst, R.D. Hey. Chichester, West Sussex, UK. John Wiley \& Sons p. $545-579$.

WOLMAN M. G., GERSON R. 1978. Relative scales of time and effectiveness of climate in watershed geomorphology. Earth Surface Processes and Landforms. Vol. 3 p. $189-208$.

Wu Y., CHEN J. 2012. Modeling of soil erosion and sediment transport in the East River Basin in southern China. Science of the Total Environment. Vol. 441 p. 159 168.

\section{Kaouther SELMI, Kamel KHANCHOUL}

\section{Ocena ladunku osadów w zlewni rzeki Mellegue, Algieria}

Erozja wodna gleby i wpływ transportu osadów na rzeki i jeziora może znacząco degradować gleby i stwarzać problemy zarówno na obszarach rolniczych, jak i dla jakości wód. Przedstawione badania prowadzono celem oceny zawiesiny wytworzonej w zlewni rzeki Mellegue w północno-wschodniej Algierii. Analizę regresji użyto do ustalenia zależności pomiędzy chwilowym odpływem wody $Q$ a chwilowym stężeniem zawiesi- 
ny $C$ na podstawie wszystkich zebranych danych i przedziałów sezonowych dla lat 1970-2003. Regresje zastosowane w tych badaniach uwzględniały podział danych na klasy bazujący na wielkości odpływu. Średnie stężenia i wielkości odpływu w poszczególnych klasach wykorzystano do skonstruowania funkcji wykładniczej poprzez transformację logarytmiczną. Ładunki osadu ustalone na podstawie stratyfikowanych krzywych natężenia przepływu wykazywały niedoszacowanie w zakresie $2-4 \%$. Średni roczny ładunek wytworzonych osadów dla okresu 34 lat badań wynosił $589.23 \mathrm{t} \cdot \mathrm{km}^{-2}$. Transport osadów był spowodowany jesiennymi ulewnymi opadami, które odpowiadały za $41 \%$ rocznych ładunków. Duża dostawa osadów w tym okresie potwierdza intensywną aktywność geomorfologiczną jesiennych sztormów wywołaną silnymi opadami i ubogą pokrywą roślinną.

Słowa kluczowe: erozja, zlewnia Mellegue, krzywe natężenia przeptywu zawiesiny, transport osadów, stężenie zawiesiny 